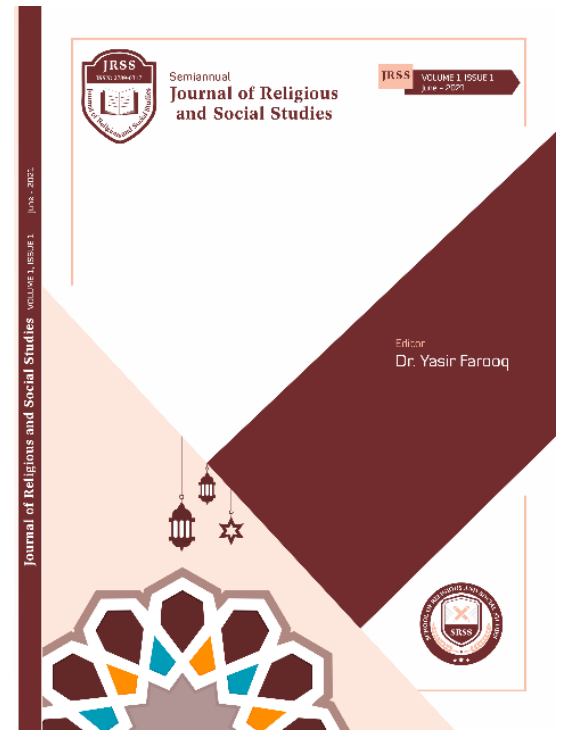

Journal of Religious and Social Studies

http://ejrss.com/index.php/jrss

ISSN (Print): 2789-0317

ISSN (online): 2789-0325

School of Religious and Social Studies,

Faisalabad (38000), Pakistan.

Book Review

\title{
'Ilm: Science, Religion and Art in Islam
}

Abdul Khaliq

To cite this article:

Abdul Khaliq, "Book Review: 'Ilm." Review of 'Ilm: Science, Religion and Art in Islam ed. by Samer Akkach." Journal of Religious and Social Studies 1, no. 1 (2021): 69-73.

DOI: https://doi.org/10.53583/jrss07.01.2021

言要 Published online: 13 Jul 2021

SU్ Submit your article to JRSS

: View this issue

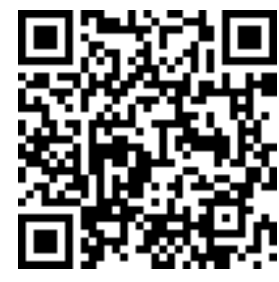

OPEN $\bigcirc$ ACCESS

Full Terms \& Conditions of access and licensing can be found at:

http:// ejrss.com/index.php/jrss/policies

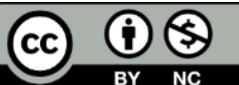




\title{
BOOK REVIEW: 'ILM: SCIENCE, RELIGION AND ART IN ISLAM
}

\author{
Abdul Khaliq ${ }^{1}$ \\ Akkach, Samer. (ed.) 'Ilm, Science, Religion and Art in Islam. \\ Adelaide: University of Adelaide Press, 2019, \\ pp. 238, ISBN: 978-1-925261-75-2.
}

The present edited book was prepared from an international conference held at the University of Adelaide in July 2016 to explore the multifaceted conceptual concept in Islam, its institution and manifestations in the world of science, religion and art. Science is normally given directly to English as 'knowledge'. This non-nuanced translation tends to hide the complexity and multifaceted nature of the arabic expression, which is both simple and complex at the same time. It is simple in meaning that is transparent and intuitively recognizable but is also complex in terms of many acquisitions, meanings, and associations that connect it with different aspects of cognition, such as different concepts, perceptions, feelings, and acquaintances. Acquisition, production and dissemination of knowledge, including teaching and learning, education and morality. Medieval Arabic lexicographers associate and thus point out that divine creation is essentially a movement of knowledge. And that the created world is a product of knowledge. Muslim mystics (Șüfis) usually refer to a sacred tradition in which God identifies the main reason for creating the world as the "desire to be known" and thus brings knowledge as the ultimate goal of religious persecution.

The book consists of 11 chapters divided into three parts. In the first chapter, "The Polarization Film: Science and Religion in Early Modern Islam" the polarization of science and religion that emerged in the 19th century is presented, to show the inconsistency between the sources of Islam before the 19th century and the classification of rational and transmitted sciences. A different trajectory in the polar Arab-Islamic context. It is necessary to study the union of religion with science, especially Islam.

1 Department of Social \& Allied Sciences, Cholistan University of veterinary and sciences,

Bahawalpur, Pakistan. 
The second chapter of the first part, "Science and Art: Anatomical Illustration in Early Islamic Optics," by Perry Sparnon, examines the claims that dissection applications and anatomical knowledge ('Ilm al-tashrih) informed the development of these paintings. The first design for the visual system and the accompanying chapters on the anatomy of the eye by Hasan Ibn al-Haytham and al-Färisì. At the same time, the chapter claims that although Muslim opticians developed at a high level in the field of optics and contributed to early scientific activities, descriptive anatomical illustrations were never important in the Kitāb al-Manäir tradition and have only been occupied to this day.

A marginal place in the writings of opticians. The chapter questions whether practices of dissection and the knowledge of anatomy ( $\mathrm{Tlm}$ al-tashrịh) informed the development of these drawings, arguing that this is the case with the first design for the visual system and Ibn al-Haytham's and al-Färisi's accompanying chapters on the anatomy of the eyes. At the same time, the chapter argues that although Muslim opticians achieved a high level of development in the field of optics and contributed to early scientific activities, descriptive anatomical illustrations were never significant carriers of knowledge in the 'ilm al-manāzir tradition and only ever occupied a marginal place in the opticians' writings.

Shaha Parpia presented the imperial Mughal hunt: A pursuit of knowledge which is third chapter which examines the sophisticated culture of hunting as an integral part of the scientific enterprise. It reveals aspects of the nature of 'scientific' knowledge from a Mughal perspective, and shows its utility and functions in that cultural context. It discusses the agency of the influential akhlāq (ethics) texts, which postulate that acquiring scientific knowledge is a religious obligation necessary to achieve perfection, and analyses how conceptions of ethics and morality impacted the promotion, perception, and practice of natural science.

The chapter explores the complex nature of scientific activities that were motivated by the Mughal hunt and their links to art, while assessing the interrelated concepts of religion, ethics, government, and science within hunting contexts in early modern Mughal history.

The fourth chapter; The House of Stars: Astronomy and the architecture of new science in early modern Lucknow (1831-49) by Katharine Bartsch and Peter Scriver, describes a state of the art facility that was distinguished equally by its architecture, not 
least the hybrid architectural science of its design, and its 'high-tech' instrumentation dedicated to practical astronomy. Acknowledging parallel experimentation ongoing in the cosmopolitan culture of pre-colonial Lucknow with the modern styles of European architecture, the observatory building and institution is also interpreted as a site of cultural intersection and diplomatic exchange, where the higher ideal of pure science was, at least briefly, shared. While the decommissioned observatory building was ultimately re-purposed for other more worldly uses, the original joint venture in scientific discovery (for which the observatory had been built) was deemed to be a failure.

In the geopolitical context in which the Indo-Islamic world had been enveloped by European imperialism, the focus of astronomy and allied sciences of observation had shifted from the heavens to the more terrestrial purposes of territorial mapping and control. Virginia Hooker discussed 'By the Pen!' Spreading 'ilm in Indonesia through Qur'anic calligraphy; the world's largest Muslim majority nation, mainstream Indonesian Muslims are seeking to deepen their knowledge of Islam. This was initially stimulated by the transnational Islamic revival of the 1970s and strengthened by a concurrent policy of Indonesia's governing new order regime. That policy restricted public expressions of Islam to culture and education and forbade any political expression of the religion. In that milieu, activities to spread knowledge of the Qur'an (' $\mathrm{Ilm}$ ) proliferated through Qur'anic study groups, Qur'anic recitation competitions, and exhibitions of Islam-inspired calligraphic art. Responding to this thirst for 'ilm, Didin Sirojuddin, an internationally recognized Indonesian calligrapher, established the Institute of Qur'anic Calligraphy (LEMKA) in 1985.

The institute is committed to spreading 'Ilm through the study of the Qur'an and the practice of Qur'anic calligraphy or teaching Islam through the pen. Its statement of purpose emphasizes that when transmitting 'ilm through the process of calligraphy, the calligrapher receives guidance, ethics, aesthetics, and creative inspiration directly from the Qur'an. Sirojuddin teaches that once students have acquired 'ilm, they must put it into practice in the form of good deeds ( $\left.A^{\prime} a m a \bar{l}\right)$ for the benefit of the individual and society. In 1998, LEMKA established the only pesantren in Indonesia devoted wholly to teaching Qur'anic calligraphy. The deliberate siting of the pesantren in the mountains of West Java inspires students to remember the Qur'anic teaching that Allah created the beauty of the universe as a source of pleasure and enjoyment. To ignore that beauty, Sirojuddin teaches, 
is to ignore an aspect of Allah's greatness. To give expression to that beauty through calligraphic art bears witness to his greatness.

Sirojuddin believes that beautifully presented Qur'anic calligraphy makes the themes and meaning of 'ilm even more beautiful and appealing than they already are so that when Muslims see the calligraphy they will be motivated to apply 'ilm through good deeds in their everyday lives.

Syed Mehboob Bukhari presented The Islamisation of ilm: ideals and realities in a globalized world next chapter starts by outlining the principles underlying Nasr's and Sardar's Islamisation of science thesis and then consider the $19^{\text {th }}$ century Islamisation discourse that informed their approach, before discussing the similarities and differences of the two discourses.

It concludes by showing how the Islamisation of 'ilm approach remains vulnerable to the commodifying hegemony of capitalism, the very force that the Islamisation process was attempting to escape in the first place. In between the mind and the heart: Kätip Çelebi's concept of 'ilm by Selen Morkoç examines Kätip Çelebi's last work, Mīzān al-ḥaqq (The Balance of Truth), which captures his inner uncertainty about the significance of 'ilm. Its aims are, first, to show how Çelebi's conceptualization and definition of 'ilm oscillated between the heart and the mind, and second, the chapter shows how he understood and approached the relationship between reason and faith as complementary rather than opposing instruments of knowledge and elements of belief. In this intertwined conception, rational sciences and philosophy were considered as necessary to religious understanding.

Third, the chapter discusses Çelebi's rational approach to answering the 21 controversial issues generated by the Kädìzzàde and Sivāsì antagonism that was hotly debated within Ottoman circles. These included the legality of music and dance in religious practices and worship, and the morality of social habits new to the times, such as smoking, opium, and coffee drinking. Faris Hajamaideen explored 'Ilm and the human body: Al-Suhrawardi's concept of the illuminated temple as the cosmological significance of the concepts of haykal and sisisiyya to show how the architecture of the human body plays a key cognitive illuminative role in the process of transformation from a fortress of darkness into a temple of light. In this process, the body and the mind work as a unified 'structure' or 'temple', wherein 'form' and 'space' work together integrally as 
'architecture' to enable the infusion of light to dematerialize the body and erase its opacity.

'Ilm and the 'architecture of happiness': The Ottoman imperial palace at Edirne/Adrianople, 1451-1877 by Susan Scollay. This chapter considers the imperial palace built by the Ottoman sultan Murat II (r. 1421-51) at Edirne in Thrace and its aesthetic context. The city had been the Ottoman seat of government for almost a century but it was not until the final years of Murat II's reign that the dynasty commissioned a palace of any significance. It also proposes that palaces of the imagination described in illustrated manuscripts, such as the Persian Shähnāma (Book of Kings) and other persianate poetic tales, were likely models for the Edirne Palace. It concludes that poetic ideals of beauty connected to ilm understood here as knowledge of literature and cultural models from elsewhere in the Islamic world, played a large part in the artistic evolution of the house of 'Uthman. James Bennett explored 'Ilm or fashion? The question of identity in the batik designs of Java; The long history of ceplokan, which is among the most popular of the design categories, with origins dating back to the pre-Islamic early classic period (c. 700-900 CE) in Java.

It examines whether the geometric motifs developed as a conscious response to ' $\mathrm{ilm}$, or rather whether they represent a process of cultural negotiation by which older HinduBuddhist textile designs were reinterpreted in the context of the new dress fashions that emerged following the ascendency of Islam in Java in the $16^{\text {th }}$ century. Curating ilm: Chapter or bridge? answered by Sam Bowker identifies the implications of these forms of knowledge when situating 'Islamic' art in the context of exhibitions, and what 'ilm may offer curators and educators as a conceptual framework. So, this edited book comprehensibly explored science and art in religion Islam. 